\title{
Performance of Lightweight Natural-Fiber Reinforced Concrete
}

\author{
Harianto Hardjasaputra ${ }^{1}$, Gino $\mathrm{Ng}^{1}$, Girum Urgessa ${ }^{2}$, Gabriella Lesmana ${ }^{1}$, \\ Steven Sidharta ${ }^{1}$ \\ ${ }^{1}$ Civil Engineering Department, Universitas Pelita Harapan, Tangerang, Indonesia \\ ${ }^{2}$ Civil, Environmental and Infrastructure Engineering, George Mason University, Fairfax, VA, USA
}

\begin{abstract}
Concrete, the most common construction material, has negligible tension capacity. However, a reinforcement material such as natural fibers, can be used to improve the tensile properties of concrete. This paper presents experiments conducted on Super Lightweight Concrete mixed with coconut fibers (SLNFRC). Coconut fibers are regarded as one of the toughest natural fibers to strengthen concrete. Coconut fiber reinforced composites have been considered as a sustainable construction material because the fibers are derived from waste. These wastes, which are available in large quantities in Asia, have to be extracted from the husk of coconut fruits and must pass a mechanical process before being added to a concrete mixture. The Super Lightweight Concrete was made by mixing concrete paste with foam agent that can reduce the overall weight of concrete up to $60 \%$ with compressive strength up to $6 \mathrm{MPa}$. The Super Lightweight Concrete is intended to be used for non-structural walls, as alternative conventional construction materials such as brick walls. The influence of coconut fibers content in increasing the flexural tensile strength of Super Lightweight Concrete was studied in this research. The fiber content studied include $0 \%, 0.1 \%, 0.175 \%$, and $0.25 \%$ by weight of cement content. Sixteen specimens of SLNFRC mini beams of $60 \mathrm{~mm}$ x 60 $\mathrm{mm} \times 300 \mathrm{~mm}$ were tested to failure to investigate their flexural strengths. The optimum percent fibers yielding higher tensile strength was found to be $0.175 \%$
\end{abstract}

Keywords: Super Lightweight Concrete, Natural-fibers, compressive, tensile strength.

\section{Introduction}

The use of lightweight concrete has increased significantly across countries all over the world. The majority of current research on concrete focuses on high-performance concrete, which is looking for satisfying demanding performance requirements, including durability. 
Meanwhile, lightweight concrete can be defined as the type of concrete that has an in-place density of less than $1840 \mathrm{~kg} / \mathrm{m}^{3}\left(116 \mathrm{lb} / \mathrm{ft}^{3}\right)$ compared to normal-weight concrete with a density in the range of 2240 to $2400 \mathrm{~kg} / \mathrm{m}^{3}$ (140 to $\left.150 \mathrm{lb} / \mathrm{ft}^{3}\right)$. Lightweight concrete is a versatile material, which consists primarily of a cement-based mortar mixed with low density aggregate (less than $880 \mathrm{~kg} / \mathrm{m}^{3}$ ) or volume of air up to $40 \%$.

Lightweight concrete has low density that leads to reduced dead load, and lower transport and handling cost. In addition, it also has a good thermal conductivity. However, lightweight concrete has low compression and flexural strength compared to normal weight concrete. The purpose of this paper is to create a lightweight concrete using foaming agent mixed with natural fibers to increase its flexural strength. Based on SNI 03-0349-1989, the density of lightweight concrete has been limited to less than $1200 \mathrm{~kg} / \mathrm{m}^{3}$ and the compression strength has a minimum value of $2.5 \mathrm{MPa}$.

The compression and flexural strength of concrete depend greatly on the composition and in particular on their density. Even though lightweight concrete discussed in this paper will not be suitable for structural member applications, determining the flexural strength will still be considered. Natural fibers, such as coconut fibers, have been successfully implemented to increase the flexural strength of concrete ( $\mathrm{Ng}$ et al, 2016). They also act like stirrup reinforcement to prevent premature concrete splitting along the tensile reinforcement and control crack width (Campione, 2013).

Coconut fiber is a waste material that can be easily available in large quantities and is very cheap. In addition, it can improve the flexural strength and form good bond in concrete. Coconut fibers also gives a lot of benefit such as no effect on environment and increase in the strength of concrete (Agrawal, 2014). Coconut fiber has the advantage of stretching beyond its elastic limit without rupturing, as well as having the power to take up a permanent stretch. It also has a unique protection to microbial degradation and salt water (Ali, 2010). Handhinia (2014) found that concrete with $0.25 \%$ fibers is the best mix based on crushing load test compared to $1 \%$ coconut fiber and regular concrete. It also reported that coconut (coir) fiber may reduce temperature by up to $30 \%$ and reduce the weight of the total concrete overall.

Table 1 shows a typical chemical composition of coconut fibers used in this research. Table 2 shows the physical properties of representative coconut fibers.

Table 1. Chemical Composition of Coconut fiber (Alam, 2014)

\begin{tabular}{|l|l|}
\hline Lingin & $45.84 \%$ \\
\hline Cellulose & $43.44 \%$ \\
\hline Hemi-Cellulose & $0.25 \%$ \\
\hline Pectin's and Related Compound & $3 \%$ \\
\hline Water Soluble & $5.25 \%$ \\
\hline Ash & $2.22 \%$ \\
\hline
\end{tabular}

Table 2. Physical Properties of Coconut Fiber (Ali, 2010)

\begin{tabular}{|l|l|}
\hline Length (in) & $6-8$ \\
\hline Density $\left(\mathrm{kg} / \mathrm{m}^{3}\right)$ & $670-1370$ \\
\hline Tenacity $(\mathrm{g} / \mathrm{Tex})$ & 10 \\
\hline Breaking Elongation $(\%)$ & $10-40 \%$ \\
\hline Diameter $(\mathrm{mm})$ & $0.1-1$ \\
\hline
\end{tabular}




\begin{tabular}{|l|l|}
\hline Rigidity of Modulus $\left(\right.$ dyne $\left./ \mathrm{cm}^{2}\right)$ & 1.8924 \\
\hline Swelling in Water $(\%)$ & $5 \%$ \\
\hline Moisture at $65 \% \mathrm{RH}$ & $10.5 \%$ \\
\hline
\end{tabular}

\section{Experimental work}

This paper presents an experimental study that investigates the use of coconut fibers in super lightweight concrete. The concrete mix design was selected based on previous super lightweight research that produce concrete with weight less than $1200 \mathrm{~kg} / \mathrm{m}^{3}$ and compression strength up to $2.5 \mathrm{MPa}$. In this case, 16 specimens of $6 \mathrm{~cm} \times 6 \mathrm{~cm} \times 30 \mathrm{~cm}$ concrete beams were made by varying the percentage of coconut fibers by weight of cement. The fiber contents studied are $0 \%, 0.1 \%, 0.175 \%, 0.25 \%$.

\subsection{Mix Designs}

Figure 1. shows the plot of lightweight concrete's mix design. The optimum mix design was selected based on previous experimental studies about lightweight concrete that produce density of concrete less than $1200 \mathrm{~kg} / \mathrm{m}^{3}$ and compression strength exceed 2.5 MPa. Table 3, Table 4 and Table 5 show the constituents of the concrete used in this research. Foaming agents were used to create the foam to fill up to $40 \%$ of final volume. The strength of concrete depends on the quantity of foam that has been used. Adding more foam yields more air in the concrete that will eventually reduce the strength.

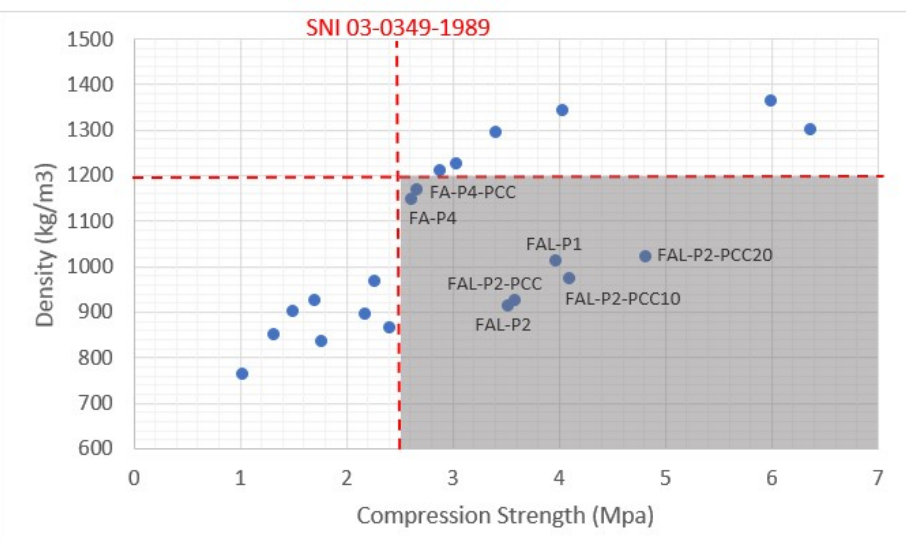

Figure 1. Mix design density vs compression strength of lightweight concrete

Table 3. Constituents of the concrete mix.

\begin{tabular}{|l|c|}
\hline Item & Comments \\
\hline Cement & Ordinary Portland cement type 1 \\
\hline Aggregate & Fine sand with particle size less than 2 mm (sieve \#10) \\
\hline Water & Regular tap water \\
\hline Foaming agent & ADT Foaming Agent \\
\hline
\end{tabular}


Table 4. Concrete paste mix proportions of FA-P4.

\begin{tabular}{|l|c|}
\hline Material & Mix Design \\
\hline Cement & $402 \mathrm{~kg} / \mathrm{m}^{3}$ \\
\hline Aggregate & $777 \mathrm{~kg} / \mathrm{m}^{3}$ \\
\hline Water & $181 \mathrm{~kg} / \mathrm{m}^{3}$ \\
\hline
\end{tabular}

Table 5. Foaming agent mix proportions.

\begin{tabular}{|l|c|}
\hline Material & Mix Design \\
\hline Foaming Agent & $5 \mathrm{~L} / \mathrm{m}^{3}$ \\
\hline Water & $150 \mathrm{~L} / \mathrm{m}^{3}$ \\
\hline
\end{tabular}

\subsection{Small Beams Experiments}

In this research, sixteen specimens of $6 \mathrm{~cm} \times 6 \mathrm{~cm} \times 30 \mathrm{~cm}$ beams were cast with varying percentages of coconut fibers as shown in Table 6 using selected mix designs. In general, procedures for mixing lightweight concrete are similar to those for normal weight concrete. However, the challenging aspect here is mixing regular concrete paste with the foaming agent.
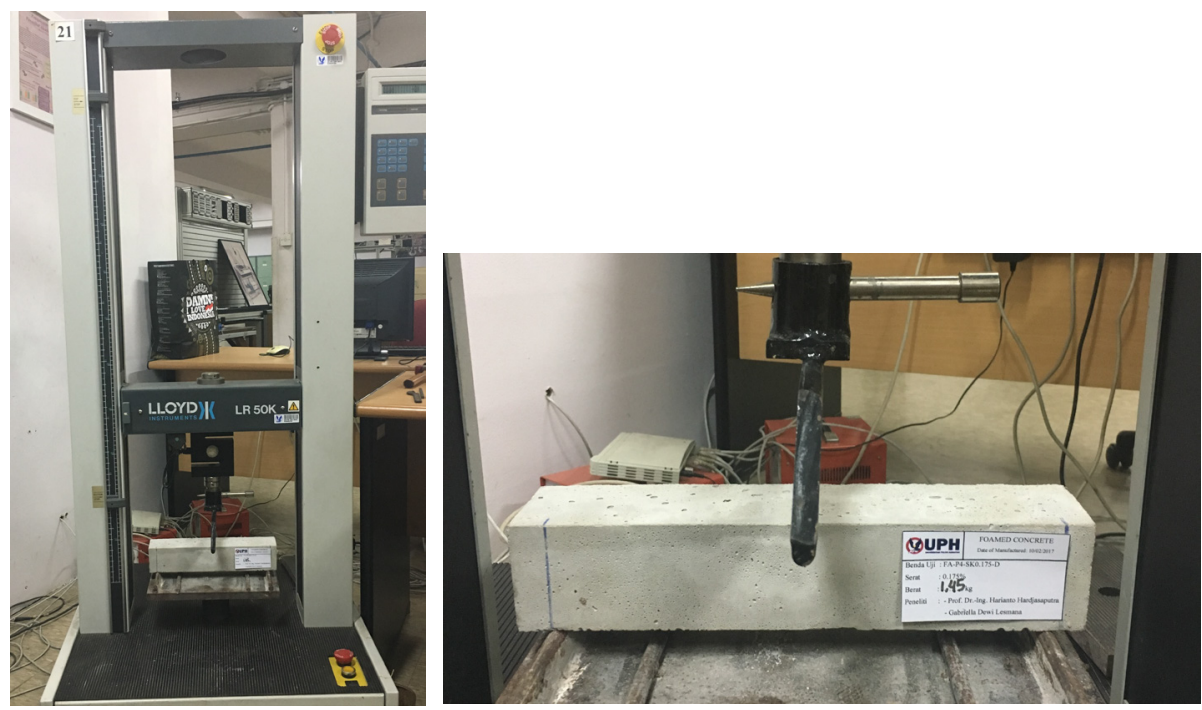

Figure 2. A small concrete beam and a test machine.

The foam concrete was made by mixing two materials, foam and concrete paste. The foaming agent and water are mixed in a mixer until the mixture transforms into foam. The foam was placed into concrete paste slowly until completely mix and becomes foamed concrete. The foamed concrete was placed into mold and the paste was flattened until it is completely distributed. The specimens were stripped from the molds twelve hours after casting and submerged in water for seven days. 
Table 6. Percent fibers in the mix design.

\begin{tabular}{|c|c|}
\hline $\begin{array}{c}\text { Experimental } \\
\text { Group }\end{array}$ & Coconut Fibers (\% weight of cement) \\
\hline 1 & $0 \%$ \\
\hline 2 & $0.1 \%$ \\
\hline 3 & $0.175 \%$ \\
\hline 4 & $0.25 \%$ \\
\hline
\end{tabular}

\section{RESULTS}

LLYOD type LR press machine with a maximum capacity of $50 \mathrm{KN}$ was used to test all the beams. This machine has transducer technology to measure the load-deformation characteristics. The results were represented by calculating fr (modulus of rupture). Table 7 shows the modulus of rupture of the concrete beams with varying coconut fiber content including the density of the beams.

Table 7. Maximum load capacity of concrete beams with varying coconut fiber content.

\begin{tabular}{|c|c|c|c|c|}
\hline $\begin{array}{c}\text { Experimental } \\
\text { Group }\end{array}$ & $\begin{array}{c}\text { Coconut Fibers } \\
\text { (\% weight of cement) }\end{array}$ & $\begin{array}{c}\text { Density } \\
\left(\mathbf{k g} / \mathbf{m}^{\mathbf{3}}\right)\end{array}$ & $\begin{array}{c}\text { Load } \\
(\mathbf{N})\end{array}$ & $\begin{array}{c}\mathbf{f r} \\
(\mathbf{M P a})\end{array}$ \\
\hline 1 & $0 \%$ & 1126.54 & 527.44 & 0.95 \\
\hline 2 & $0.1 \%$ & 1136.57 & 787.42 & 1.42 \\
\hline 3 & $0.175 \%$ & 1138.89 & 927.97 & 1.68 \\
\hline 4 & $0.25 \%$ & 1148.15 & 399.21 & 0.72 \\
\hline
\end{tabular}

Figure 2 shows the average of modulus of rupture results. It shows that adding coconut fiber until $0.175 \%$ clearly increases the flexural strength of the lightweight concrete. However, adding excessive fibers reduces the strength. In fact, adding $0.25 \%$ (by the weight of cement) of coconut fiber has same modulus of rupture with normal lightweight concrete. In this case, the effective amount of fiber that can be used is $0.175 \%$, where it is shown to increase the flexural strength up to $76 \%$ when compared to regular concrete mix with no coconut fibers.

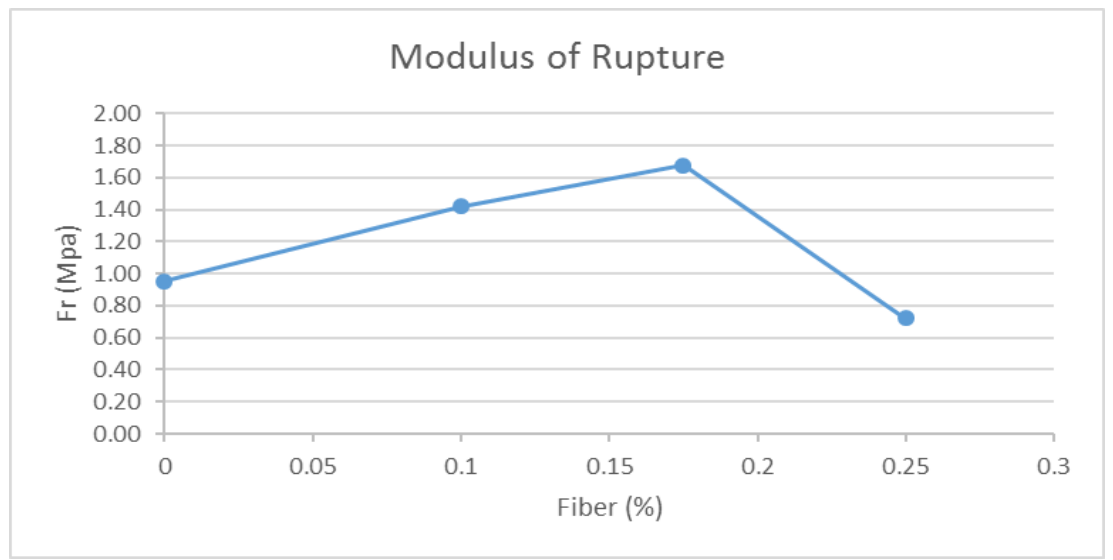

Figure 3. Modulus of rupture of concrete beams with cocunt (coir) fiber reinforcement. 


\section{CONCLUSION}

The results show that the mix design has successfully met code requirements. In addition, it also shows that coconut fibers have a good effect in the mix design. The addition of coconut fibers clearly increased flexural strength and stiffness of the concrete. The optimum percent fibers from this research was found to be $0.175 \%$. However, adding excessive fibers resulted in reduction of the tensile strength due to bonding issue between fibers and concrete. Additional research is needed to determine if there is an optimum value of coconut fiber between $0.175 \%-0.25 \%$ by weight of cement.

The first Author would like to acknowledge that a part of this research has been done during his research visit at TU Berlin- Germany, granted by Konrad Adenauer Stiftung.

\section{REFERENCES}

1. Ali, M., Natural Fibres as Construction Materials, Journal of Civil Engineering and Construction Technology. Vol. 3, No. 3, pp. 80-89 (2012)

2. Agrawal, R.A, Dhase, S.S. and Agrawal, K.S., Coconut Fiber in Concrete to Enhance its Strength and Making Lightweight Concrete, International Journal of Engineering Research and Development, Vol. 9, No. 8, pp. 64-67(2014)

3. Ng, G.P., Urgessa, G.S., Bayleyegn, Y. and Hardjasaputra, H., Mechanical Properties of Coconut Fiber-Reinforced Concete, Resilient Structures and Sustainable Construction, Valencia, Spain, (2017)

4. Hardjasaputra, H., Tirtawijaya, J. and Fernandez, D.A., The Application of Natural Fibers in Concrete Mixing to Increase Shear Strength and Performance of Concrete Beam, Proceeding of The First International Seminar on Sustainable Infrastructure and Built Environment in Developing Countries, Indonesia, (2009).

5. Hardjasaputra. H, Ng. G, Guntur. P, Widjajakusuma. J, Rahardja. S. Pembuatan Lantai Berbasis Semen Sebagai Bahan Bangunan Hijau Berserat Sabut Kelapa Dengan Teknik Basah dan Teknik Press [Study of cement based flooring (tile) using coconut fiber with wet and press method]. Proceeding of Konferensi Nasional Teknik Sipil 8, ITSBandung, Indonesia, (2014)

6. Ramakrishna, G. and Sundararajan, T., "Impact strength of a few natural fibre reinforced cement mortar slabs: A comparative study", Journal of Cement Concrete Composites, Vol. 27, No. 5, pp. 547-553, (2005)

7. Campione, G. Flexural and Shear Resistance of Steel Fiber-Reinforced Lightweight Concrete Beams, Journal of Structural Engineering, Vol. 140, (2013). 